\title{
Relationship between interblink interval and dopamine
}

This article was published in the following Dove Press journal:

Clinical Ophthalmology

26 April 2013

Number of times this article has been viewed

\section{Thomas I Lemon \\ Rupali D Shah}

School of Medicine, Cardiff University, University Hospital of Wales, Cardiff,

United Kingdom
Correspondence:Thomas I Lemon School of Medicine, Cardiff University,

University Hospital of Wales,

Heath Park, Cardiff CFI4 4XW,

United Kingdom

Email lemonti@cf.ac.uk

\section{Dear Editor}

An interesting study recently reported by Johnston et $\mathrm{al}^{1}$ investigated the interblink interval between dry and normal eye subjects. The authors concluded that this interval was reduced in dry eyes in comparison with normal eyes, that there was a greater variability in interblink intervals in normal eyes, and that the parameters were useful for diagnosis of dry eye disease. ${ }^{1}$

Using a method that measured the interblink interval achieved exactly what the authors expected, and enabled better discrimination between normal and dry eye subjects. As the authors state, monitor usage may have impaired their data slightly, and hence a comparative study of the same cohort but using a fixed visual stare would have been both interesting and relevant. The variability seen, as the authors discuss, could be related to an integral homeostatic mechanism. Taylor et al, who investigated and published an interesting paper relating to dopamine's role in blink rate, suggested the ventromedial part of the caudate nucleus in particular is critically involved. ${ }^{2}$

We thank Johnston et al for reporting this enlightening study. Should it be repeated or augmented, a comparative study of fixed visual stare to monitor usage in the same participants and also comments on the relationship with dopamine levels would be interesting.

\section{Disclosure}

The authors report no conflicts of interest in this correspondence.

\section{References}

1. Johnston PR, Rodriguez J, Lane KJ, Ousler G, Abelson MB. The interblink interval in normal and dry eye subjects. Clin Ophthalmol. 2013;7:253-259.

2. Taylor JR, Elsworth JD, Lawrence MS, Sladek JR, Jr, Roth RH, Redmond DE, Jr. Spontaneous blink rates correlate with dopamine levels in the caudate nucleus of MPTP-treated monkeys. Exp Neurol. 1999;158:214-220. 


\section{Author's response}

Patrick R Johnston'

John Rodriguez'

Keith J Lane'

George Ousler'

Mark B Abelson ${ }^{1,2}$

'Ora Inc, Andover, MA, USA; ${ }^{2}$ Schepens Eye Research Institute and Harvard Medical School, Boston, MA, USA

Correspondence: Patrick R Johnston

Ora Inc, 300 Brickstone Sq, 3rd Floor,

Andover, MA 01810 , USA

Tel +l 9786858900

Fax + I 9786890020

Email pjohnston@oraclinical.com

We thank Lemon and Shah for their insightful comments. The finding that dopamine mediates spontaneous blink through the caudal nucleus provides the mechanism behind altered blink states in diseases such as Parkinson's disease and schizophrenia. Fatigue has also been linked to impaired dopaminergic transmission, ${ }^{1,2}$ and it is fascinating to speculate that the changes observed in blinking could be in part centrally mediated. A local role of dopamine might also be proposed. The finding of dopaminergic nerves adjacent to goblet cells suggests a role in the regulation of these mucin-secreting cells which are critical to a stable tear film. ${ }^{3}$ Dopamine receptors have also been isolated from bovine cornea. $^{4}$
Our field of study is at a crossroads between local, ocular, and central stimuli, as we challenge subjects both by desiccation of the ocular surface and by visual task to assess effects on blinking. The suggestion by Lemon and Shah to assess subjects under fixed-stare conditions is well taken. In fact, we intend to study alterations in blink patterns under various conditions of task and nontask, trying to tease out changes due to ocular dryness and those due to discomfort. It is quite possible that sympathetic dopaminergic stimulation from the stressed cornea and conjunctiva results in blinking, demonstrating its fundamental role in both central and local control of this critical function.

\section{Disclosure}

The authors report no conflicts of interest in this correspondence.

\section{References}

1. Stenman E, Lilja A. Increased monoaminergic neurotransmission improves compliance with physical activity recommendations in depressed patients with fatigue. Med Hypotheses. 2013;80(1):47-49.

2. Felger JC, Li L, Marvar PJ, et al. Tyrosine metabolism dugin interferonalpha administration: Association with fatigue and CSF dopamine concentrations. Brain Behav Immun. October 13, 2012. [Epub ahead of print].

3. Dartt DA, McCarthy DM, Mercer HJ, Kessler TL, Chung EH, Zieske JD. Localization of nerves adjacent to goblet cells in rat conjunctiva. Curr Eye Res. 1995;14(11):993-1000.

4. Grub M, Mielke J, Rohrbach M, Schlote T. Dopaminrezeptoren des Hornhautepithels und -endothels [Dopamine receptors of the corneal epithelium and endothelium]. Klin Monbl Augenheilkd. 2012; 228(8):822-825. German.
Clinical Ophthalmology

\section{Publish your work in this journal}

Clinical Ophthalmology is an international, peer-reviewed journal covering all subspecialties within ophthalmology. Key topics include: Optometry; Visual science; Pharmacology and drug therapy in eye diseases; Basic Sciences; Primary and Secondary eye care; Patient Safety and Quality of Care Improvements. This journal is indexed on

Submit your manuscript here: http://www.dovepress.com/clinical-ophthalmology-journal

\section{Dovepress}

PubMed Central and CAS, and is the official journal of The Society of Clinical Ophthalmology (SCO). The manuscript management system is completely online and includes a very quick and fair peer-review system, which is all easy to use. Visit http://www.dovepress.com/ testimonials.php to read real quotes from published authors. 